\title{
Ecological Significance of Diversion Water from Yangtze River to Relieve Taihu Lake Through the Wangyu River*
}

\author{
ZHAI Shuhua \\ Taihu Basin Water Resources Protection Bureau, Shanghai 200434, China
}

\begin{abstract}
Taihu Lake is the third largest fresh water lake in China, locating in Yangtze Delta as the richest area of China. At present, eutrophication problem is severe in Taihu Lake. This paper, in view of ecological system, presents analysis of the composition structural characteristics of Taihu Lake environment regarded as a whole ecological system, energy and substances circulation between ecological factors. The Taihu Lake ecological environment is proceeding a lake evolution period, i.e. middle-eutrophic to eutrophic. Therefore the diversion water'from Yangtze River to Taihu Lake through the Wangyu River acts to change external agent function for Taihu ecological system, i.e. increasing water quantity of Taihu Lake may rise water level and speed up flow exchanging. Moreover, with harnessing measures for pollution sources to reduce input of nutrients, natural evolution procedure of Taihu ecological environment may slow down to subsequently improve Taihu ecologiçal environment.
\end{abstract}

Keywords: Taihu Lake, Wangyu River, ecological system, lake evolution

\section{Geographical location of Taihu Lake and the Wangyu River}

Taihu Basin is located in the Yangtze River Delta of China, covering southern part of Jiangsu Province, Zhejiang Province and Shanghai, which is one of the richest areas in China. Taihu Lake is at the center of the basin and the Wangyu River is a main water passage connecting the Yangtze River with Taihu Lake. The geographical location of Taihu Lake and the Wangyu River is shown in Fig. 1.

\section{Formation and evolution of Taihu ecological system}

Generally speaking, Taihu Lake was a gulf formed by inland faulting, later it developed to be a lake in type of shallow lagoon by alluviation of the Yangtze River, Qiantang River and river channels of western mountainous area. Since Taihu Lake is located in a subtropical region and

* Received 1997-02-25; accepted 1998-03-27. 
water network plain, human 's activities have produced great influence on its development.

According to lake evolution theory, dystrophic lake is being developed into eutrophic lake and sediments and dissolved nutrients of land area system are always conveyed to lake by rivers to make dystrophic lake more and more shallow and productivity higher and higher. Eventually, it becomes a marshland. The natural procedure of lake development is presented as evolution of eutrophication function, that is caused by geological and living things functioning in long geological period. Therefore, eutrophication is a slow natural function, but more often, human activities may speed up this procedure.

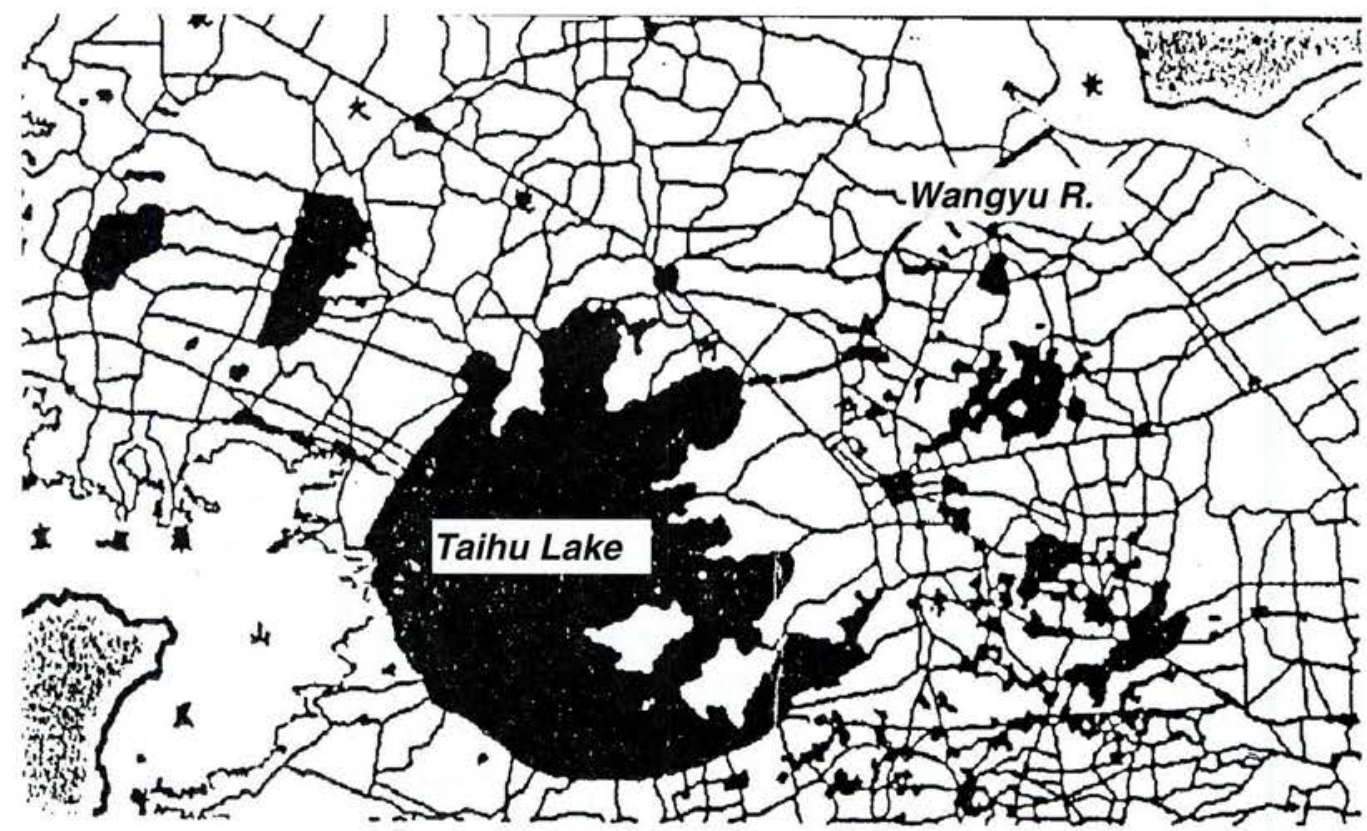

Fig. 1 Geographical location of Taihu Lake and the the Wangyu River

Taihu Lake is a shallow lake, with abundant sunlight and high productivity, and is relatively liable to be a eutrophic lake under natural conditions. As high speed development of land area economy, intensive agriculture makes runoff of farmland produce great amount of nutrients. Township enterprises increase industrial wastes entering the lake, as a result, ecological structure and ecological quantity have been changed, moreover, with reclamation activities in 1950's 1960's, the lake flow has been changed, too. All these activities have finally increased input of river sediments and speeded up Taihu Lake shallowing and its eutrophication procedures. Serious algae bloom in Taihu Lake in 1990 symbolizes the transformation of ecological system of Taihu Lake from meso-eutrophic to eutrophic.

\section{Composition and characteristics of Taihu Lake ecological system}

Taihu Lake ecological system is composed of two subsystems, i.e. land area ecological subsystem and Taihu Lake water body ecological subsystem. Taihu Lake water body ecological subsys- 
tem means the energy moving and substance circulation within the water body. The land area ecological subsystem, except for Taihu Lake water body itself, includes all energy and substance factors, which produce influence on the variation of water body ecological subsystem. In this paper, the land ecological subsystem is taken as external function producing influence on Taihu Lake water body ecological subsystem and the influence is analyzed. Taihu Lake water body ecological subsystem is composed of four different levels, i.e. producer, consumer, resolver and environmental factor. The environmental factor includes concentration of nutrients, temperature, hydraulic condition, transparency, bottom load condition and morphological characteristics. The morphological characteristics of Taihu Lake appear wide water surface, shallow water, western bank line in straight and eastern bank with more capes. Taihu Lake's water surface area is 2338 $\mathrm{km}^{3}$, water depth 1.5-2.5 m, average water depth $1.9 \mathrm{~m}$, more islands in lake' with total area of islands $90 \mathrm{~km}^{2}$. Since water surface broad and lake shallow, the main current is wind-driven current. The current is mainly influenced by wind and the lake geometry. Taihu Lake is flat, lake bed is mainly composed of hard loess substance, only individual areas with mud about 2-3 m in thickness, mainly fine silt and clay. The sediments of modern time are conveyed by inflow, outflow and current in lake, and effected on the lake geometry. Sedimentation speed in eastern Taihu Lake is the greatest, submerged sandy ridge composed of coarse sand is formed along the coast of western lake section, south to Dapukou, northern part and eastern lake and bay area. Hydraulic characteristics and geometry of Taihu Lake determine high waves and high turbidity in the center of Taihu Lake, so that eutrophication will not be liable to happen. However, eastern cape area is flow stationary area, low flow speed and high transparency which are favorable conditions for eutrophication. In view of the water chemical characteristics, as lake bank and bay area directly accept rich nutrients conveyed by rivers of inland, which provides nutritional conditions for eutrophication taking place in Taihu banks and bay areas. Therefore, Taihu banks and bay areas are the most fragile section of Taihu water ecological system, extremely liable to be attacked by land area ecological subsystem to lead to variation of water body ecological system structure. The producers of Taihu Lake water body subsystem include algae, phytoplankton and big aquatic plants. The consumers include zooplankton and fishes. According to the analysis of variation of composition factors of Taihu Lake ecosystem, (comparison of the situations between 1981 and 1990), the concentration of nutrients increased. The dissolved $\mathrm{P}$ doubled in Wulihu area; $\mathrm{NH}_{3}-\mathrm{N}$ increased by 2.5 times; the number of algae increased by nearly 40 times during the period of 1981-1990. As the year 1990 was drought, the water level of Taihu was lower than $2.5 \mathrm{~m}$, so algae broke up in Taihu Lake in that year. The ecosystem of Taihu Lake catchment is transferred from a natural ecological system into an artificial ecological system in subtropical plain. Here the soil is fertile, vegetation is mainly man-planted crops, food chain is simple, ecological environment is extremely fragile and difficult to prevent large amount of pollutants from entering and difficult to recover its original condition after polluted. Taihu land area ecological system, as external force function of Taihu water body ecological subsystem, is characterized by great development of river network connecting with Taihu Lake water body. There are more than 200 rivers including the 
Wangyu River flowing into Taihu Lake, which directly provides a base for Taihu Lake for energy and substance exchange. In addition, since dense population in land, per $\mathrm{km}^{2}$ population is more than 1000 . Industry and agriculture are extremely developed, high application rate of resources and cropping index of farmland, high input of chemical fertilizer and pesticide. Furthermore, township enterprises have rapidly developed, which makes pollution quantity produced in land area increasing and water quality worsened, eventually Taihu Lake water quality worsened too and ecological structure changed. Therefore, the land area ecological system of Taihu Lake is closely related to the water body ecological system, they form a whole system. The characteristics of mutual affection are:

1) Frequent exchange of substance flow: Taihu Lake, as a water supply source, directly supplies water to surrounding cities, and also supplies water to cities and townships and towns of downstream by river channels. People living along the banks, industry and agriculture drain wastewater to the lake by rivers or directly to the lake, the pollutants enter the lake together with water supplied to the lake, particularly large amount of $\mathrm{P}$ nutrients entered affects ecological quality of Taihu Lake;

2) Mutual effect of energy: Taihu water body ecological system maintains its own development, it must absorb, transfer and utilize external energy source such as absorbing solar energy. So Taihủ Water ecological system- becomes acceptor of energy and substance input by external environment and land area ecological system meanwhile it also optimize land area ecological environment by its own functions. Taihu ecological system structure composition is shown in Taihu Lake Ecological Structure Diagram (Fig. 2).

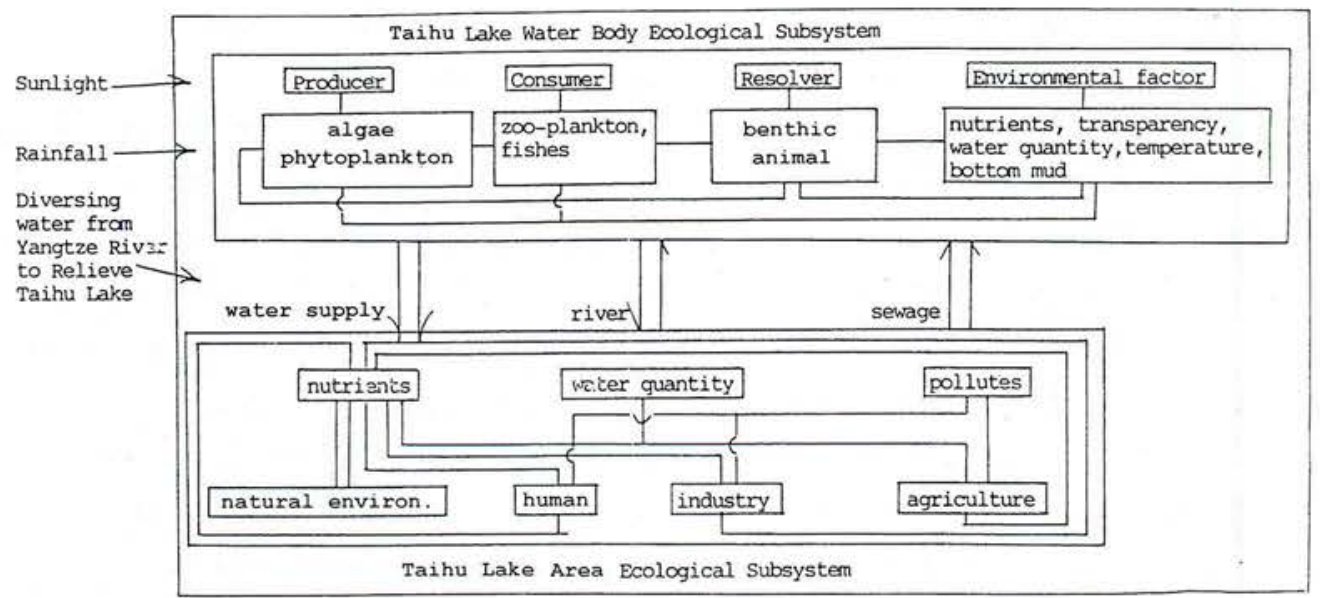

Fig. 2 Taihu lake ecological system composition 


\section{Ecological Significance of Diversion water from the Yangtze River to Relieve Taihu Lake through the Wangyu River}

Various factors of Taihu Lake ecological system affect each other, so change of one factor may bring about changes of other factors. Except for mutual effect of factors within the system as cause of the factors' changes, they will also work as external force factors to promote change of the system. Diversion water from the Yangtze River to relieve Taihu Lake is a controllable external force factor to change Taihu water body ecological system.

As indicated above, Taihu land area ecological system has become an artificial ecological system from natural ecological system. Human activities have not only changed water quantity into Taihu Lake but also changed water quality, and subsequently changed Taihu water body ecological system. Moreover, human beings directly drain sewage to Taihu Lake and draw clear water from Taihu Lake, which directly leads to variation of Taihu Lake water body ecological system. Diversion water from the Yangtze River to relieve Taihu Lake through the Wangyu River is to supplement water to Taihu water body ecological system and dilute concentration of nutrients and regulate Taihu Lake hydraulic condition to control eutrophication function and "Algae Bloom".

So called the Wangyu River is a canal excavated in recent years upon original river channel, it is $60.8 \mathrm{~km}$ long from the Yangtze River to Taihu Lake and river bed is $70-90 \mathrm{~m}$ wide. Pumping stations with both pumping and drainage functions are constructed along banks for water supply and drainage. In dry year, 2.8 billion $\mathrm{m}^{3}$ of water may yearly diverted by those pumping stations, accounting for $69 \%$ of water quantity from upstream of Taihu Lake and $60 \%$ of the total capacity of Taihu Lake, which may obviously change hydraulic condition of Taihu water body ecological system. With the harnessing measures of pollution sources along the Wangyu River, the conditions of nutrients may be greatly improved. In accordance with calculation, the Wangyu River may (guarantee rate $94 \%$ ) divert water 2.14 billion $\mathrm{m}^{3}$ in the type of 1971 with concentration of COD into lake averaging $5.47 \mathrm{mg} \cdot \mathrm{L}^{-1}$; it may divert water 3 billion $\mathrm{m}^{3}$ in the type of 1978 with concentration of COD averaging $5.38 \mathrm{mg} \cdot \mathrm{l}^{-1}$.

On the whole, diversion water from the Yangtze River to relieve Taihu Lake through the Wangyu River as an external function to change Taihu water body ecological system must gain response of various factors within Taihu ecological system. This proposed project makes it possible to supply water quantity and reduce concentration of nutrients as a key point for controlling eutrophication of Taihu Lake. It also makes human action as a reaction force to the natural procedure of lake eutrophication, so as to make the water environment of Taihu Lake developed according to human demands. 
